\title{
PENTINGNYA KONTEKSTUALISASI PADA PENDIDIKAN KRISTEN
}

\author{
Donna Mutiara Nainggolan ${ }^{1}$, Nehemia Nome ${ }^{2}$, Ridolf S.Th Manggoa ${ }^{3}$ \\ donnamutiara71@gmail.com ${ }^{1}$, nehemianome@gmail.com ${ }^{2}$, ridolfm@yahoo.com ${ }^{3}$ \\ ${ }^{1}$ Sekolah Tinggi Teologi Pelita Dunia \\ 2Sekolah Tinggi Teologi Injili Arastamar (SETIA) Jakarta \\ ${ }^{3}$ Sekolah Tinggi Teologi Injili Arastamar Ngabang
}

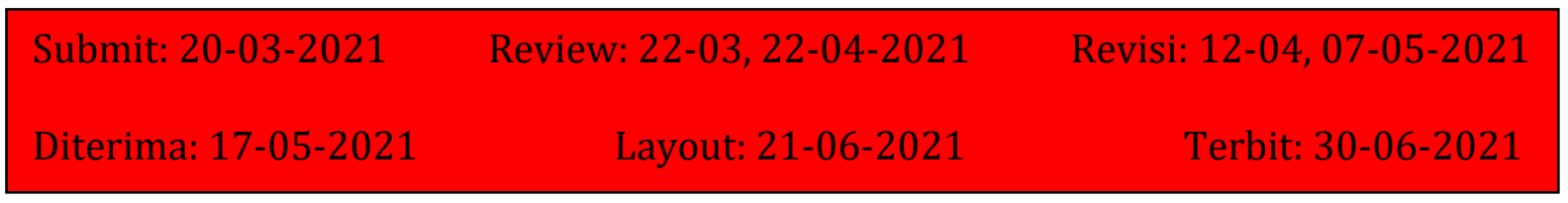

\begin{abstract}
This study examines Christian education. In particular, trying to examine the importance of Christian education is designed in a contextual manner. In order to be more effective in achieving the goals of Christian education. This research uses qualitative methods specifically for literature review. Through this approach, the researcher obtained several conclusions. First, Christian education must be designed in a contextual manner to make it easier for students to understand and understand any content taught in it. Second, Jesus is the great teacher who also taught contextually. Third, contextual Christian education is understood in several important principles, namely: (1) Christian education must be applied in accordance with the teaching style and strategy of teaching Jesus, (2) Christian education must be adapted to the situation of the industrial era 4.0, (3) Christian education must be able to accepted by every age layer, (4) Christian education must not be rigid but must be dynamic, implementative, and applicable, and (5) Christian education must provide radical transformation or change.
\end{abstract}

Keywords: Contextual Christian Education, Transformative Education, Biblical Education.

\begin{abstract}
Abstrak
Penelitian ini meneliti tentang pendidikan Kristen. Secara khusus mencoba meneliti pentingnya pendidikan kristen didesain secara kontekstual. Supaya lebih efektif bagi tercapainya tujuan pendidikan Kristen. Penelitian ini menggunakan metode kualitatif dengan spesifik kepada kajian pustaka. Melalui pendekatan tersebut, peneliti memperoleh beberapa kesimpulan. Pertama, pendidikan kristen harus didesain secara kontekstual guna memudahkan peserta didik memahami dan mengerti setiap konten yang diajarkan di dalamnya. Kedua, Yesus adalah sang guru yang Agung yang juga mengajar secara kontekstual. Ketiga, pendidikan kristen yang kontekstual dipahami dalam beberapa prinsip penting, yakni: (1) pendidikan Kristen harus diterapkan sesuai dengan gaya dan strategi mengajar mengajar Yesus, (2) pendidikan Kristen harus disesuaikan dengan situasi era industri 4.0, (3) pendidikan Kristen harus dapat diterima oleh setiap lapisan usia, (4) pendidikan Kristen tidak boleh kaku namun harus dinamis, implementatif, dan aplikatif, dan (5) pendidikan Kristen harus memberikan transformasi atau perubahan yang radikal.
\end{abstract}


PENTINGNYA KONTEKSTUALISASI PADA PENDIDIKAN AGAMA KRISTEN (Donna

Mutiara Nainggolan, Nehemia Nome, Ridolf S.Th Manggoa)

Kata Kunci: Pendidikan Kristen Kontekstual, Pendidikan Transformatif, Pendidikan Alkitabiah.

\section{Pendahuluan}

Pendidikan Kristen merupakan pendidikan yang bertujuan untuk membawa setiap peserta didik mengenal dan mengerti kehendak Allah dalam Tuhan Yesus guna dipraktikkan dan membawa perubahan yang signifikan dalam kehidupan setiap peserta didik. Hal ini sejalan dengan tanggung jawab seorang guru Pendidikan Agama Kristen. John M. Nainggolan mengatakan beberapa tanggung jawab seorang guru Pendidikan Agama Kristen, meliputi, tentang sejauh mana Pendidikan Kristen di setiap sekolah mampu memberikan dampak yang baik bagi perkembangan kerohanian anak. Kemudian sejauh mana tanggung jawab sekolah dalam menerapkan Pendidikan Kristen kepada anak secara bertanggungjawab dan bermutu. Tidak hanya di situ saja, tetapi perlu juga memperhatikan sejauh mana peranan guru PAK mewujudkan tujuan PAK di gereja dan di sekolah. Terakhir, sejauh mana tanggung jawab orangtua dalam mendukung pelaksanaan tugas pendidikan Agama Kristen di sekolah. ${ }^{1}$

Kemudian Arozatulo Telaumbanu menambahkan beberapa tanggung jawab seorang guru Pendidikan Agama Kristen yang menurutnya meliputi, seperti: guru memberikan dirinya kepada murid, guru menjadi teladan kepada murid, guru membawa murid berjumpa dengan Kristus, dan guru membawa murid menuju perubahan hidup. ${ }^{2}$ Itulah sebabnya, setiap apa yang dilakukan oleh guru Pendidikan Agama Kristen harus sejalan dengan apa yang menjadi tujuan dari pendidikan Kristen.

Agar dapat mencapai tujuan dari pendidikan Kristen, maka setiap guru pendidikan Kristen perlu mencari figur yang dapat dijadikan contoh dan teladan dalam mengajar. Termasuk melihat seperti apa figur tersebut mengajar supaya dapat diterapkan dalam praktik mengajar di kelas.

Berbicara masalah figur dan pribadi yang akan diteladani, maka setiap guru Pendidikan Agama Kristen harus melihat kepada Yesus Kristus. Oleh karena Yesus sendiri dalam Yohanes 13:13 telah mengklaim dirinya sebagai Guru. Sehingga tidak keliru apabila beberapa ahli pendidikan Kristen menyebut Yesus sebagai guru yang agung.

Apabila membaca buku-buku, artikel atau tulisan-tulisan tentang pendidikan Kristen, maka di sana seringkali dijumpai ungkapan "Yesus adalah Guru yang Agung". Di mana ungkapan ini muncul dari salah satu gelar yang seringkali dialamatkan kepada Yesus, selain Tuhan, Anak Allah, Anak Manusia, yaitu Rabi. Seperti yang dikemukakan oleh Daniel Suyoto, "Yesus sebagai Rabi bukti bahwa ada perbedaan di antara Yesus dan para rabi Yahudi yang lain di dalam pengajaran-Nya, karena pengajaran-Nya disertai dengan kuasa yang dimiliki-Nya dalam melaksanakan perbuatan tanda-tanda dan mungkin juga perkataan-perkataan yang disampaikan-Nya (Mat. 7:28-29)". ${ }^{3}$

Bahkan Sutoyo menjelaskan bahwa Yesus mengajar para murid agar mereka meneladaninya dan Ia menggunakan lingkungan sebagai tempat belajar yang baik. Para murid yang mengikuti Yesus diperhadapkan pada situasi dan kondisi riil yang sesuai dengan materi pelajaran yang diberikan Yesus. Para murid sebagai pembelajar secara langsung belajar dalam suatu lingkungan yang variatif. ${ }^{4}$

\footnotetext{
1 John M. Nainggolan, Guru Agama Kristen (Bandung: Jurnal Info Media, 2006), 29.

${ }^{2}$ Arozatulo Telaumbanua, "Peranan Guru Pendidikan Agama Kristen Dalam Membentuk Karakter Siswa," FIDEI: Jurnal Teologi Sistematika dan Praktika 1, no. 2 (2018): 219-231.

3 Daniel Sutoyo, "Yesus Sebagai Guru Agung," Jurnal Antusias 3, no. 5 (2014): 64-85.

4 Ibid.
} 
Hal yang identik juga dikemukakan oleh Yesi Tamara dkk., dengan mengatakan, "Yesus menjadi Guru yang Agung karena Ia menjadi Guru yang menjadikan seluruh kehidupan-Nya dan pengajaran menjawab kebutuhan manusia yang berdosa. Dalam Alkitab tampak bahwa Yesus adalah guru yang menggunakan metode yang kreatif dan kontekstual. Ia menggunakan pengalaman hidup para pendengar-Nya untuk menyampaikan pesan yang hendak disampaikan-Nya". ${ }^{5}$ Karnawati dkk, juga mengatakan, "Yesus dalam Injil, dapat dikatakan telah menyediakan sebuah lingkungan belajar yang tidak monoton, hal ini terlihat dari setiap proses pembelajaran yang Dia lakukan secara langsung berhadapan dengan lingkungan yang bervariasi, baik berupa lingkungan fisik maupun sosial" ${ }^{6}$

Berdasarkan beberapa pendapat di atas maka kemampuan Yesus menerapkan strategi, model hingga metode mengajar yang kontekstual, membuatnya banyak dikagumi oleh audiens atau orang yang mendengarkan pengajarannya. Yesus mampu memberikan pengajaran yang berbeda, berkualitas bahkan membumi dalam kehidupan setiap pendengar. Hal ini terjadi karena Yesus menerapkan prinsip kontekstualisasi dalam mengajar. Setiap guru Pendidikan Agama Kristen seharusnya dapat menerapkan pendekatan dan strategi yang sama sehingga tujuan pengajarannya dapat tercapai.

Mengapa selama ini guru Pendidikan Agama Kristen sulit memberikan sebuah pengajaran yang efektif? Mengapa selama ini, seolah pendidikan agama Kristen hanya merupakan sesuatu yang cenderung normatif saja, tidak dapat memberikan perubahan radikal pada kehidupan setiap peserta didik? Salah satu jawabannya adalah pendidikan agama Kristen belum diterapkan secara kontekstual. Hal ini lah yang akan diteliti dalam penelitian ini. Seperti apa natur dan prinsip dari pendidikan Kristen yang kontekstual. Sehingga dapat dilihat betapa pentingnya pendidikan Kristen yang kontekstual.

Dengan demikian pendidikan Kristen harusnya diterapkan atau dilakukan secara kontekstual. Akan tetapi, seperti apa bentuk pendidikan kontekstual yang dimaksud? Hal inilah yang akan diteliti dalam tulisan ini.

\section{Metode Penelitian}

Pada penelitian ini menggunakan pendekatan kualitatif yang menitikberatkan pada kajian pustaka. Adapun pustaka yang dikaji adalah pustaka seputar pendidikan Kristen, tafsiran dari beberapa kitab Injil yang berbicara tentang pelayanan Yesus selama di bumi. Pustaka-pustaka itu dielaborasi untuk memperoleh pemahaman dari topik penelitian yang diteliti ini. Menurut Adi Putra, "Semua kajian kualitatif bertumpu pada kajian literatur melalui sumber-sumber primer seperti buku, artikel jurnal, ensiklopedia dan majalah."7

\section{Pembahasan}

5 Yesi Tamara et al., "Profesionalitas Yesus Sang Guru Agung Dalam Penggunaan Media Pembelajaran," Didache: Journal of Christian Education 1, no. 1 (2020): 65-76.

${ }^{6}$ K Karnawati, H Hosana, and I Putu Ayub Darmawan, "Lingkungan Proses Pembelajaran Yesus," Veritas Lux Mea (Jurnal Teologi Dan Pendidikan Kristen) 1, no. 2 (2019): 76-89.

${ }^{7}$ Adi. Putra, "Kajian Biblika Terhadap Makna "Ta Stigmata Tou Iesou” Dalam Galatia 6:17,"” SUNDERMANN: Jurnal Ilmiah Teologi, Pendidikan, Sains, Humaniora dan Kebudayaan 13, no. 1, no. March, 2020 (2020). 
PENTINGNYA KONTEKSTUALISASI PADA PENDIDIKAN AGAMA KRISTEN (Donna

Mutiara Nainggolan, Nehemia Nome, Ridolf S.Th Manggoa)

Pada bagian pembahasan ini akan diteliti tentang apa itu kontekstualisasi khususnya dalam gereja, selanjutnya menjelaskan tentang Yesus yang mengajar secara kontekstual berdasarkan bukti-bukti dari Kitab Injil. Setelah membahas kedua hal di atas, barulah masuk dalam pembahasan Pendidikan Kristen yang kontekstual.

\section{Kontekstualisasi}

Perlu sekali memberikan penjelasan tentang definisi dari kontekstualisasi untuk selanjutnya nanti dikaitkan dengan pendidikan Kristen. Hesselgrave dan Rommen memberikan definisi dengan mengatakan, "Presenting the supracultural message of the gospel in culturally relevant terms". ${ }^{8}$ Kemudian menurut Fleming, kontekstualisasi adalah "How the gospel revealed in Scripture authentically comes to life in each new cultural, social, religious and historical setting". ${ }^{9}$ Kemudian Moreau mendefenisikannya dengan mengatakan, "The process whereby Christians adapt the forms, content, and praxis of the Christian faith so as to communicate it to the minds and hearts of people with other cultural backgrounds. The goal is to make the Christian faith as a whole-not only the message but also the means of living out our faith in the local setting-understandable". ${ }^{10}$

Hesselgrave mendefenisikan kontekstualisasi dengan mengatakan, bahwa itu merupakan sebuah usaha yang dilakukan untuk menyajikan pesan Injil yang suprakultural dalam istilah yang relevan secara budaya. Kemudian Fleming mengatakan, bahwa kontekstualisasi adalah bagaimana Injil diungkapkan dalam Kitab Suci secara otentik menjadi hidup di setiap tatanan budaya, sosial, agama dan sejarah yang baru. Terakhir, pendapat Moreau yang mengatakan bahwa kontekstualisasi merupakan proses di mana orang Kristen menyesuaikan bentuk, isi dan praksis dari iman Kristen untuk mengkomunikasikannya ke dalam pikiran dan hati orang-orang dengan latar belakang budaya lain. Tujuannya untuk menjadikan budaya kristiani secara keseluruhan. Bukan hanya pesannya tetapi juga cara menghayati keyakinan kita dalam lingkungan lokal menjadi dapat dimengerti.

Yakob Tomatala mengatakan, "'Kontekstualisasi adalah refleksi ideal dari setiap orang Kristen dalam konteks hidupnya atas Injil Yesus Kristus. Yang terpenting di sini ialah bagaimana seharusnya Injil yang utuh itu ditaburkan sehingga membawa keseimbangan yang tampak dari refleksi teologi si penerima Injil”. ${ }^{11}$

Bahkan seorang teolog Indonesia terkenal, Eka Darmaputera juga memberikan pendapat tentang (teologi) kontekstualisasi. Baginya, (teologi) kontekstualisasi adalah teologi itu sendiri. Artinya, teologi dapat disebut sebagai teologi apabila ia benar-benar kontekstual. Secara lebih sederhana dapat dikatakan bahwa teologi adalah upaya untuk merumuskan penghayatan iman kristiani pada konteks, ruang, dan waktu tertentu. ${ }^{12}$

Sekalipun definisi di atas lebih kepada definisi kontekstualisasi Teologi, namun setidaknya prinsip dari kontekstualisasinya dapat diadopsi ke dalam pemahaman kontekstualisasi Pendidikan Agama Kristen. Berdasarkan definisi yang telah dijelaskan di atas, maka dapat disimpulkan bahwa kontekstualisasi dalam pendidikan Kristen adalah sebuah usaha yang dilakukan oleh guru PAK untuk mengajar dan membuat sebuah materi ajara yang bersumber dari Alkitab (Kitab Suci) untuk selanjutnya diajarkan sehingga menjadi hidup dalam kehidupan praktis peserta didik. Supaya lebih mudah diterapkan dan diaplikasikan, maka seringkali media dan strategi

8 David J. Hesselgrave; Edward Rommen, Contextualization: Meaning, Methods, and Models (Pasadena: William Carey Library, 1989), 1.

${ }_{9}^{9}$ Bruce C. Fleming, Contextualization of Theology: An Evangelical Assessment (Pasadena: William Carey Library, 1980), 13-14.

${ }^{10}$ A. Scott Moreau, Contextualizing the Faith:A Holistic Approach (Grand Rapids, MI: Baker Academic, 2018), 36.

11 Yakob Tomatala, Teologi Kontekstualisasi (Suatu Pengantar) (Malang: Gandum Mas, 2018), 2.

12 Ibid., 2-3. 
penyampaiannya menggunakan kearifan lokal atau budaya setempat yang membuatnya lebih mudah dipahami dan diterima oleh masyarakat setempat.

Akan tetapi perlu untuk digarisbawahi bahwa kontekstualisasi dalam pendidikan Kristen tidak boleh mengubah substansi dari konten pengajaran. Melainkan hanya sebatas membuat situasi mengajar lebih nyaman, lebih sesuai dengan situasi dan kondisi peserta didik, hingga materi yang lebih mudah dipahami demi terciptanya perubahan yang signifikan pada diri peserta didik.

\section{Yesus Mengajar Secara Kontekstual}

Yesus menerapkan strategi, model hingga metode mengajar yang kontekstual, membuatnya banyak dikagumi oleh audiens atau orang yang mendengarkan pengajarannya. Contoh konkrit dalam Injil yang menunjukkan betapa Yesus mengajar secara kontekstual, seperti yang tercatat dalam Lukas 5:1-11 dan juga dalam Matius 13:1-23.

Pada Lukas 5:1-11, menceritakan ketika Yesus berada di pantai danau Genezaret dan orang banyak mengerumuninya karena mereka hendak mendengarkan pengajaran Yesus. Pada ayat 2-3 menjelaskan bahwa, "Ketika Yesus melihat perahu di tepi pantai..., Ia naik ke dalam salah satu perahu.. lalu Ia duduk dan mengajar orang banyak dari atas perahu". Leon Morris mengatakan, "Jesus then sat down (the customary position for teaching) and taught the people from the boat". ${ }^{13}$ Artinya, bahwa Yesus ketika naik ke atas perahu dan mengambil posisi duduk, maka itu menandakan bahwa Dia telah siap untuk mengajar. Dan memang dalam narasi perikop itu menjelaskan bahwa Yesus mengajarkan mereka. Bahkan secara konkret, I. Howard Marshall mengatakan, "Bagi Yesus, mengajar di tepi laut bagaikan memakai perahu menjadi semacam mimbar".14

Apa yang telah dilakukan oleh Yesus ketika mengajar seperti yang telah disaksikan oleh Lukas menunjukkan bahwa Dia telah melakukan kontekstualisasi dalam menggunakan media atau fasilitas yang lebih familiar bagi audiensnya. Sehingga ini dapat menjadi contoh yang baik bagi penerapan strategi mengajar secara kontekstualisasi di STT-STT yang ada di Indonesia. Sehingga dapat meminimalisir masalah serta menunjang terciptanya proses belajar mengajar yang efektif dan efisien.

Selanjutnya dalam Matius 13:1-23, yang mengisahkan tentang Yesus yang mengajar menggunakan perumpamaan. Yesus menggunakan perumpamaan gunanya supaya setiap pengajaran yang disampaikan lebih mudah dipahami dan dimengerti oleh audiensnya. Pada Matius 13:1-23, Yesus menggunakan perumpamaan tentang seorang penabur. Bahkan setiap fitur yang terdapat dalam perumpamaan itu sangat familiar dengan para audiensnya.

J. J. de Heer mengatakan, "Paling tepat bila kita menganggap bahwa di dalam pasal 13 telah dikumpul sejumlah perumpamaan yang diucapkan oleh Yesus pada waktu yang tidak sama. Terlalu padat kalau Yesus mengucapkan tujuh perumpamaan dalam satu khotbah. Dalam hal mengajar Yesus sangat bijaksana; hal memakai tujuh perumpamaan dalam satu khotbah saja, dapat dianggap sebagai hal yang kurang bijaksana; jalan itu tidak ditempuh Yesus".15

Artinya Yesus yang mengajar menggunakan perumpamaan (sekalipun tidak dalam waktu yang sama menggunakan tujuh perumpamaan) menunjukkan betapa Dia adalah

${ }^{13}$ Leon Morris, The Tyndale New Testament Commentaries: Luke (Surabaya: Momentum, 2007), 124.

${ }^{14}$ G.J. Wenham. D.A. Carson, R.T. France, J.A. Motyer, ed., Tafsiran Alkitab Abad Ke-21 (MatiusWahyu) (Jakarta: YKBK/OMF, 2017), 156.

15 J.J. de Heer, Tafsiran Alkitab Injil Matius (Jakarta: BPK Gunung Mulia, 2003), 252. 
PENTINGNYA KONTEKSTUALISASI PADA PENDIDIKAN AGAMA KRISTEN (Donna

Mutiara Nainggolan, Nehemia Nome, Ridolf S.Th Manggoa)

guru yang bijaksana dan agung. Sehingga alangkah baiknya apabila setiap guru PAK mencontoh dan mengaplikasikan cara dan metode mengajar Yesus ini. Bahkan sangat memungkinkan mengajar mata kuliah yang abstrak, sulit dan rumit dapat menggunakan metode-metode yang praktis seperti yang pernah dilakukan oleh Yesus supaya setiap siswa dapat memahaminya dengan mudah dan benar.

Apa yang telah dilakukan oleh Yesus dalam mengajar jelas sangat kontekstual, dan sekali lagi memberikan pengajaran bahwa bahkan dalam mengajar pun terlihat dengan jelas misi yang bersifat inkarnasi. Oleh karena Yesus dengan penuh kerendahan hati mau bersusah payah memikirkkan metode, strategi dan gaya mengajar seperti apa yang akan digunakannya guna setiap content mengajarnya mudah dipahami.

Hal ini tentunya terkoneksi dengan inkarnasi-Nya, di mana Dia rela meninggalkan surga dan menjadi manusia demi menjangkau manusia yang berdosa dan lemah supaya mereka akhirnya memiliki hubungan dan persekutuan dengan Bapa. Ketika mengajar, Yesus juga memperlihatkan hal yang sama. Dia memilih cara, strategi yang tepat guna memudahkan pendengarnya memahami isi pengajaran-Nya. inilah prinsip misiologi yang harus digarisbawahi oleh setiap dosen ketika hendak mengajar, terutama dengan kondisi mahasiswa yang beragam secara suku dan memiliki kemampuan yang terbatas.

Berangkat dari prinsip misiologi di atas, maka praktik yang ideal yang harus dilakukan dan diterapkan adalah (1) memilih metode mengajar yang kontekstual guna memudahkan para audiens memahami dan mengerti setiap materi ajar, dan (2) ketika mengajar, ingat bahwa yang yang harus diprioritaskan adalah setiap audiens memahami kehendak Allah dan mengubah dan melahirkan barukan mereka supaya memiliki hidup yang mempermuliakan Tuhan.

\section{Pendidikan Kristen yang Kontekstual}

Setelah memperhatikan dan menegaskan pada pembahasan sebelumnya, bahwa Yesus mengajar dengan kontekstual, maka pada pendahuluan bagian ini perlu ditegaskan bahwa pendidikan Kristen pun perlu diterapkan secara kontekstual. Supaya pendidikan Kristen lebih mudah diterima, mengakar dalam kehidupan praktis peserta didik dan juga dapat memberikan perubahan signifikan dalam kehidupan peserta didik. Seperti yang dikemukakan oleh Imanuel Agung dan Made Astika bahwa, "Seyogyanya para pengajar Kristen, khususnya yang terlibat dalam pelaksanaan PAK di sekolah memperhatikan persoalan mengenai metode mengajar ini, supaya peserta didik benarbenar mengalami perjumpaan dengan Tuhan Yesus dan firman-Nya, sehingga mereka dapat mengenal Tuhan Yesus secara pribadi". ${ }^{16}$ Dengan demikian pendidikan Kristen harus berdampak sistemik dan signifikan pada kehidupan peserta didik guna memberikan perubahan dan pengenalan akan Kristus secara radikal.

Lalu seperti apa implementasinya pendidikan Kristen yang kontekstual? Atau seperti apa prinsip-prinsip yang harus diikuti dan dipenuhi oleh pendidikan Kristen supaya dapat masuk kriteria kontekstual?

Pertama, pendidikan Kristen harus diterapkan sesuai dengan gaya dan strategi mengajar mengajar Yesus. Pada bagian sebelumnya, telah disinggung bahwa Yesus adalah guru yang agung yang mengajar secara kontekstual. Mengapa? Oleh karena Yesus dapat mengajar secara baik menggunakan metode, pendekatan hingga memanfaatkan kearifan lokal setempat. Seperti perahu yang dapat dijadikan sebagai mimbar mengajar, atau menggunakan perumpamaan guna materi pengajarannya mudah dipahami oleh setiap peserta didiknya.

16 Imanuel Agung and Made Astika, "Penerapan Metode Mengajar Yesus Menurut Injil Sinoptik Dalam Pelaksanaan Pendidikan Agama Kristen Di SMA Gamaliel Makassar," Jurnal Jaffray 9, no. 2 (2011): 147-171. 
Bahkan Yesus sebagai guru membuktikan diri sangat dicintai oleh audiensnya, karena Dia dapat mengajar dan menyampaikan materi dengan sangat baik dan mudah dipahami bahkan memberikan perubahan dalam kehidupan audiensnya. Menurut Talizaro Tafonao, Yesus adalah guru bagi masyarakatnya seperti yang juga terdapat dalam Injil Matius 4:25, bahwa:

\begin{abstract}
"Maka orang banyak berbodong-bondong mengikuti Dia. Mereka ada yang datang dari Galilea, Dekapolis, dari Yerusalem dan dari Yudea, juga dari seberang sungai Yordan". Selanjutnya, Yesus tidak hanya melayani dan mengajar orang-orang yang datang kepada- Nya, tetapi Yesus pergi melayani dan mengajar diberbagai tempat "Demikianlah Yesus berkeliling ke semua kota dan desa; Ia mengajar dalam rumah-rumah ibadat dan memberitakan Injil Kerajaan Surga serta melenyapkan segala penyakit dan kelemahan" (Matius 9:35). Matius 4:23 mencatat "Maka Yesus pun mulai berbicara dan mengajar mereka..." (5:2). Orang banyak "takjub mendengar pengajaran-Nya sebab Ia mengajar sebagai orang yang berkuasa, tidak seperti ahli-ahli Taurat" (Mrk 1:22). Bahkan para Ahli Taurat "takjub mendengar pengajaran-Nya, sebab perkataan-Nya penuh kuasa" (Luk 4:32) dan orang banyak mengakui, "...pengajaran-Mu benar" dan menegaskan, "pengajaran-(Nya) dari Bapa” (Yoh 6:45) dan mengajak orang “...belajarlah pada-Ku” (Mat 11:29). Yesus sendiri mengkalim diri, "memang Aku lah Guru dan Tuhan" (Yoh 13:13). Akhirnya, Dia memerintahkan "...jadikanlah segala bangsa murid $\mathrm{Ku}$... dan ajarlah mereka" (Mat 28:20). ${ }^{17}$
\end{abstract}

Dengan demikian dapat dilihat betapa pentingnya pendidikan Kristen meneladani pola dan tindakan Yesus dalam mengajar. Supaya tujuan dari pendidikan Kristen dapat terealisasikan. Tidak hanya itu, apabila pendidikan Kristen hendak mengikuti pola dan strategi mengajar Yesus, maka pendidikan Kristen juga harus bermuara kepada amanat agung atau pengutusan untuk memberitakan Injil. Seperti yang dikemukakan oleh Yosia Belo, "Pendidikan agama Kristen dalam Matius 28:19-20 dapat dipahami bahwa PAK bertujuan untuk memuridkan, PAK berarti untuk memperbaiki kekeliruan dan menuntun kepada kebenaran, dan PAK adalah Amanat Agung". ${ }^{18}$ Apabila hal ini telah terpenuhi maka pendidikan Kristen sudah dapat dikategorikan sebagai pendidikan yang kontekstual seperti yang telah dipraktikkan oleh Yesus, sang guru Agung itu. Parhusip, Hutahaean, dan Elda Theresia juga mengemukakan hal yang sama dengan menyebutkan beberapa fungsi dari Pendidikan Kristen, yakni:

1) Memampukan peserta didik memahami kasih dan karya Allah dalam kehidupan sehari-hari, (2) Membantu peserta didik mentransformasikan nilai-nilai kristiani dalam kehidupan sehari-hari. Sedangkan tujuan Pendidikan Agama Kristen itu sendiri adalah: (1) Untuk mengajak, membantu, menghantar, seseorang untuk mengenal kasih Allah yang nyata dalam Yesus Kristus, (2) Untuk membawa anak didik percaya dan menerima Yesus Kristus sebagai Tuhan dan Juruselamat hidupnya, (3) Untuk menambahkan nilai-nilai Kristiani

17 Talizaro Tafonao, "Yesus Sebagai Guru Teladan Dalam Masyarakat Berdasarkan Perspektif Injil Matius," Khazanah Theologia 2, no. 1 (2020): 52-60.

18 Yosia Belo, “Pendidikan Agama Kristen Dalam MatiuS 28: 19-20," Jurnal LUXNOS 1, no. 2 (2020): 127-133. 
PENTINGNYA KONTEKSTUALISASI PADA PENDIDIKAN AGAMA KRISTEN (Donna

Mutiara Nainggolan, Nehemia Nome, Ridolf S.Th Manggoa)

juga memberikan wawasan dan pengetahuan keberanian firman Tuhan secara kognitif (pengetahuan), afektif (sikap), dan psikomotor (keterampilan). ${ }^{19}$

Kedua, pendidikan Kristen harus disesuaikan dengan situasi era industri 4.0. Menurut Mark Phillips Eliasaputra, Martina Novalina, dan Ruth Judica Siahaan, Salah satu bentuk inovasi dalam Revolusi Industri 4.0 adalah pemanfaatan media sosial yang mengalirkan informasi begitu derasnya tanpa henti kepada masyarakat, sekaligus juga mengubah posisi masyarakat dari pemirsa yang pasif menjadi produsen informasi yang aktif. Melalui Facebook, Twitter, Instagram, YouTube dan sebagainya, konten informasi yang mencapai masyarakat telah berubah dari karya jurnalistik dan ilmiah beserta norma dan etika yang melekat padanya menjadi karya bebas ciptaan siapa saja, di mana karya seni dan tulisan cerdas bercampur dengan sampah dan kebohongan. ${ }^{20}$

Sedangkan menurut Dirk Roy Kolibu dan Stenly Paparang, ciri-ciri era industry 4.0, di mana ada sifat "ingin lebih tahu" pada manusia untuk bersikap dan bertindak bebas, berkembang, dan dapat terintegrasi dengan lainnya di situasi yang berbeda, sehingga kecepatan dalam bidang informasi dan teknologi berpengaruh pada peradaban manusia melebihi ekspektasi pemikiran manusia sebelumnya. Pengaruh ini tampak dalam pergeseran tatanan sosial budaya, ekonomi, agama, dan politik, yang memerlukan keseimbangan baru antara nilai-nilai (etika), pemikiran dan cara-cara kehidupan yang berlaku pada konteks global dan lokal. ${ }^{21}$ Bahkan Kolibu dan Paparang menyimpulkan bahwa,

"Fenomena bahwa adanya pengaruh yang signifikan dari Revolusi Industri 4.0 tak dapat dihindari, melainkan dinikmati tetapi dengan mempergunakan berbagai analisis dan pengamatan terhadap pengaruh baik-buruknya dalam berbagai bidang termasuk bidang Pendidkan Kristen itu sendiri. Sistem Pendidikan Kristen perlu menunjukkan sikap kritis untuk menjawab tantangan Revolusi Industri 4.0 berdasarkan pengkajian internal dan pula mengambil berbagai hasil penelitian terkait dengan kemajuan industri di berbagai bidang kehidupan manusia, sehingga ketika melakukan revolusi di bidang pendidikan Kristen, para pemangku kepentingan dapat mengadopsi berbagai penemuan dan data terkini, hasil survei dan lain sebagainya, termasuk mengadopsi empat kapabilitas yang diperlukan di era Revolusi Industri 4.0 seperti yang dijelaskan Wibowo, kemudian menambahkan beberapa poin signifikan mengenai kompetensi untuk disesuaikan dengan konteks Pendidikan Kristen itu sendiri. Revolusi Pendidikan Kristen di era Revolusi Industri 4.0 adalah hal penting karena dengan demikian sistem Pendidikan Kristen berpotensi menghasilkan pengaruh yang besar, baik internal maupun eksternal. Segala upaya yang dilakukan ditempuh dengan melihat peluang dan pengamatan yang cermat agar apa yang ditetapkan sebagai bagian dari revolusi dapat terwujud dan mengalirkan hasil yang baik bagi masyarakat mikro maupun makro".22

19 Bongsu Parhusip, Hasahatan Hutahaean, and Elda Theresia, "Penerapan Model Think-Pair and Share Dalam Meningkatkan Hasil Belajar PAK Pada Siswa SMP,” Didache: Journal of Christian Education 1, no. 2 (2020): 117-140.

${ }^{20}$ Mark Phillips Eliasaputra, Martina Novalina, and Ruth Judica Siahaan, "Tantangan Pendidikan Agama Kristen Di Era Revolusi Industri 4.0 Dan Pasca Kebenaran," BONAFIDE: Jurnal Teologi Dan Pendidikan Kristen 1, no. 1 (2020): 1-22.

${ }^{21}$ Dirk R Kolibu and Stenly R Paparang, "Revolusi Pendidikan Kristen Di Era Industri 4.0," Jurnal Dinamika Pendidikan 13, no. 2 (2020): 108-119.

22 Ibid. 
Dengan demikian, pendidikan Kristen yang kontekstual adalah pendidikan yang dapat diterapkan atau memanfaatkan perkembangan teknologi era industri 4.0. Sehingga dapat berdampak kepada generasi $\mathrm{Z}$ yang juga lahir, tumbuh dan berkembang pada era ini. Oleh karena pendidikan Kristen juga harus dapat mengajar mereka guna mereka dapat bertumbuh dan mengenal Kristus. Itulah kegunaan pendidikan Kristen yang kontekstual.

Ketiga, pendidikan Kristen idealnya dapat diterima oleh setiap lapisan usia. Pendidikan Kristen dapat diterima oleh berbagai jenjang usia, mulai dari lansia, dewasa, pemuda hingga anak-anak. Itulah sebabnya pendidikan kristen harus dikontekstualisasikan berdasarkan kebutuhan setiap jenjang usia tersebut.

Misalnya, untuk lansia, maka Pendidikan Kristen diharapkan menjawab permasalahan dan kebutuhan mereka. Pendidikan Kristen diharapkan menjadi solusi dan jawaban atas setiap pergumulan mereka. Termasuk menjadi sumber penghiburan menghadapi masa tua dengan kondisi fisik yang sudah semakin menurun bahkan mungkin dengan berbagai penyakit yang dialami. Kemudian untuk usia dewasa, pendidikan Kristen juga harus dapat menjawab pergumulan mereka, misalnya dalam pekerjaan, tanggung jawab rumah tangga hingga bagaimana membesarkan dan mendidik setiap anak yang hadir dalam keluarga.

Untuk pemuda dan remaja, pendidikan Kristen menjadi tolok ukur, bahkan penunjuk arah untuk mengarahkan kehidupan mereka selalu pada koridor yang benar sesuai dengan yang dikehendaki oleh Tuhan. Itulah sebabnya, pendidikan Kristen harus selalu dikontekstualisasikan dengan kehidupan mereka.

Terakhir, pendidikan Kristen juga harus kontekstual bagi anak-anak. Sekalipun masih anak-anak, namun mereka juga perlu untuk diajar dan dibentuk dalam pengajaran Firman Tuhan yang benar. Saenom memberikan tujuh alasan (7) mengapa pendidikan agama Kristen juga perlu untuk anak-anak. Menurutnya, (1) Anak-anak memiliki martabat, hormat, dan nilai jiwa, (2)Anak-anak bergantung untuk segala sesuatunya kepada Allah (fisik dan rohani), (3) Anak-anak bertanggung jawab kepada Allah sebagai pencipta mereka, (4) Anak-anak memiliki keinginan yang hakiki untuk memuja dan mengidolakan seseorang atau sesuatu, (5) Anak-anak diciptakan sama di hadapan Allah, (6) Anak-anak berbeda satu dengan yang lain, dan (7) Anak-anak merupakan manusia seutuhnya. ${ }^{23}$

Saenom menambahkan tujuan pendidikan kristen untuk anak yang dibaginya ke dalam dua prospek tujuan, yakni tujuan jangka pendek dan jangka panjang. Tujuan jangka pendek yakni membawa anak-anak kepada kedewasaan rohani dalam iman Kristennya yang mencakup menerima Kristus sebagai Tuhan dan juruselamat pribadinya dan ia mampu mengambil keputusan sesuai dengan nilai-nilai Kristen. Sedangkan untuk tujuan jangka panjang yakni meliputi: (1) memuridkan kepemimpinan keluarga di masa yang akan datang, (2) menyediakan pengajaran dan pengalaman bagi anak dalam mengekspresikan iman Kristen mereka yang di dapat dari para orangtua mereka, dan (3) Mempersiapkan anak memiliki materi-materi ajaran yang alkitabiah dari orangtuanya untuk menjadi bekal pengajaran anak-anak mereka dikemudian hari. ${ }^{24}$

${ }^{23}$ Saenom, Pendidikan Agama Kristen Untuk Anak (Jakarta: Penerbit Vieka Wahana Semesta (Views), 2016), 29-31.

${ }^{24}$ Ibid., 33-34. 
PENTINGNYA KONTEKSTUALISASI PADA PENDIDIKAN AGAMA KRISTEN (Donna

Mutiara Nainggolan, Nehemia Nome, Ridolf S.Th Manggoa)

Dengan demikian pendidikan Kristen harus dikontekstualisasikan supaya dapat diterima oleh berbagai jenjang usia. Oleh karena setiap jenjang usia memiliki pergumulan dan masalahnya masing-masing.

Keempat, pendidikan Kristen tidak boleh kaku namun harus dinamis, implementatif, dan aplikatif. Menurut Hope S. Antone,

“Teori tersebut harus dinamis ketimbang statis. Seperti waktu dan ruang berpindah dan berganti, seperti kejadian dan pengalaman terus berjalan dan mengalir, teori pendidikan perlu merespons dengan segera dan tepat. Oleh karena itu, setiap teori pendidikan pasti memiliki suatu kisah di belakangnya. Seringkali kisahnya merupakan suatu konflik, ketegangan, realisasi dari suatu kekurangan atau kebutuhan akan sesuatu, atau visi dari sesuatu yang baik bagi komunitas atau masyarakat". ${ }^{25}$

Berdasarkan apa yang dikemukakan oleh Antone di atas maka dapat dikatakan bahwa pendidikan Kristen yang kontekstual haruslah dapat tetap menghadirkan sebuah pendidikan yang transformatif dalam berbagai situasi, kondisi hingga keadaan. Termasuk dalam kondisi pandemi covid-19 sekarang, pendidikan Kristen harus tetap diajarkan kepada peserta didik dengan penyesuaian yang tepat. Seperti memanfaatkan teknologi informasi, menggunakan sistem belajar online (zoom, google meet, dll.) dan memaksimalkan alat peraga dalam pengajaran supaya tetap implementatif dan aplikatif. Sebagaimana Hermanto Sihotang, menjelaskan "Beberapa prinsip-prinsip penerapan $e$ pedagogy dalam mengaplikasikan media teknologi informasi ini dalam proses belajar mengajar PAK di sekolah dapat berupa: modul materi ajar yang telah disiapkan oleh guru, dapat diterima oleh peserta didik, sebelum materi itu diajar, sehingga pada saat tatap muka di dalam kelas, peserta didik sudah siap dengan segala macam tanggapan dan pertanyaan. Kemudian, juga dapat dilakukan dalam hal pelaksanaan tugas. Tugas dapat dikumpulkan secara online, sehingga memudahkan bagi semua pihak dalam melaksanakan tugasnya, menghemat waktu dan biasa serta tenaga. Demikian juga dalam pengaturan dan informasi jadwal doa, ibadah dan lainnya. Jika menggunakan dan memanfaatkan perrkembangan teknologi tersebut, semua dapat dilakukan dengan baik". ${ }^{26}$

Bahkan Hermanto Sihotang menambahkan bahwa pembelajaran konvensional tidak lagi sepenuhnya menjadi andalan, namun di tengah kemajuan teknologi saat ini diperlukan variasi metode yang lebih memberikan kesempatan untuk belajar dengan memanfaatkan aneka sumber, tidak hanya dari man power seperti halnya guru. Pembelajaran yang dibutuhkan adalah dengan memanfaatkan unsur teknologi informasi, dengan tidak meninggalkan pola bimbingan langsung dari pengajar dan pemanfaatan sumber belajar lebih luas. Konsep ini disebutnya dengan system belajar blended learning. ${ }^{27}$

Dengan demikian, menjadikan pendidikan Kristen yang kontekstual memang sudah sepatutnya harus dinamis, implementatif bahkan aplikatif. Pendidikan Kristen tidak boleh dikalahkan oleh keadaan, situasi bahkan kondisi. Sebaliknya, pendidikan Kristen harus selalu implementatif pada berbagai keadaan termasuk pada masa

${ }^{25}$ Hope S. Antone, Pendidikan Kristiani Kontekstual: Mempertimbangkan Realitas Kemajemukan Dalam Pendidikan Agama (Jakarta: BPK Gunung Mulia, 2010), 11.

${ }^{26}$ Hermanto Sihotang, "Penggunaan Media Teknologi Informasi Dalam Pembelajaran Pendidikan Agama Kristen Di Masa Pandemi Covid-19," IMMANUEL: Jurnal Teologi dan Pendidikan Kristen 1, no. 2 (2020): 63-75.

27 Ibid. 
pandemi covid-19 sekarang ini. Bahkan bagi Sihotang, pada masa pandemi saat ini, pendidikan Kristen sebaiknya diaplikasikan dengan sistem blended learning.

Kelima, pendidikan Kristen harus memberikan transformasi atau perubahan yang radikal. Menurut Ferry Yang, "Pendidikan Kristen memiliki suatu sistem di mana kita sebagai pendidik-pendidik Kristen memiliki tujuan, atau target pencapaian, yaitu transformasi total dari orang-orang berdosa sehingga mereka boleh menjadi orangorang kudus dari Allah". ${ }^{28}$

Untuk dapat mencapai tujuan pendidikan kristen yang transformatif, maka setiap guru pendidikan agama Kristen diwajibkan untuk menjadikan Alkitab sebagai sumber primer pengajaran mereka. Seperti yang dikemukakan Louis Berkhof, "Guru sekolah Kristen harus rajin mengambil prinsip-prinsip ini dengan cermat dalam sistem pemerintahan sekolah dan dalam semua tindakan pendisiplinan... Alkitab merupakan standar yang harus mereka pakai untuk memimpin anak-anak yang dipercayakan kepada mereka". ${ }^{29}$

Menurut Yushiko D. Monding, "Pendidikan kristiani transformatif dapat memberikan suatu pembelajaran iman dengan kerangka solidaritas, kasih dan pengharapan kepada komunitas iman, khususnya masalah-masalah seputar seksualitas yang juga menjadi suatu pergumulan yang dihadapi setiap orang percaya". ${ }^{30}$ Artinya dari apa yang dikemukakan oleh Monding di atas, maka dapat dipahami bahwa pendidikan kristen yang transformatif adalah pendidikan yang memberikan dampak perubahan dalam kehidupan peserta didik. Apabila sebelumnya peserta didik memiliki kehidupan yang rusak, hancur karena dosa, maka melalui pendidikan kristen mengalami transformasi atau perubahan ke arah yang dikehendaki oleh Kristus.

Kemudian Frets Keriapy memberikan penjelasan tentang pendidikan kristen transformatif dalam konteks Indonesia. Baginya, "Pendidikan transformatif berbasis pada multikultural, di mana pendidikan yang berbasis pada budaya lokal merupakan strategi yang bisa digunakan dalam proses belajar mengajar di sekolah. Oleh karena Indonesia merupakan negara yang majemuk (multikultural), maka para nara didik pun yang dimiliki sekolah tidak lahir atau berasal dari satu jenis etnis atau kebudayaan. Oleh karena itu, melihat budaya sebagai sarana yang bisa dipakai sebagai proses penunjang pendidikan akan mengajarkan nara didik untuk dapat saling menghargai satu dengan yang lain. Hidup dalam toleransi. Hal ini tentunya harus dimulai dari guru sebagai pengajar. Guru merupakan role model yang secara langsung dilihat oleh nara didik. Oleh karenanya, proses pendidikan multikultural yang transformatif harus lahir dari guru atau tenaga pendidik sehingga tujuan pendidikan yang mengubah hidup dapat betulbetul terealisasikan dalam kehidupan para nara didik". ${ }^{31}$

Sekali lagi dalam pandangan Keriapy juga menegaskan hal yang sama dengan Monding bahwa pendidikan kristen yang transformatif harus memberikan dampak perubahan dalam kehidupan peserta didik. Dengan demikian penting sekali pendidikan dibuat dan didesain dalam bentuk kontekstual supaya dapat efektif dalam kehidupan peserta didik.

${ }^{28}$ Ferry Yang, Pendidikan Kristen (Surabaya: Momentum, 2018), 17.

${ }^{29}$ Louis Berkhof; Cornelius van Til, Foundations of Christian Education (Surabaya: Momentum, 2012), 177.

${ }^{30}$ Yushiko D Monding, "Tinjauan Teologis Tentang Pendidikan Seks Dari Perspektif Pendidikan Kristiani Transformatif," Jurnal Teologi Pengarah 2, no. 2 (2020): 173-182.

${ }^{31}$ Frets Keriapy, "Pendidikan Kristiani Transformatif Berbasis Multikultural Dalam Konteks Indonesia," REGULA FIDEI: Jurnal Pendidikan Agama Kristen 5, no. 2 (2020): 82-93. 


\section{Kesimpulan}

Setelah diteliti dan dijelaskan, maka berikut akan dikemukakan beberapa kesimpulan dari penelitian ini.

Pertama, pendidikan kristen harus didesain secara kontekstual guna memudahkan peserta didik memahami dan mengerti setiap konten yang diajarkan di dalamnya. Karena pemahaman kontekstual itu sendiri adalah bagaimana pesan injil dalam pengajaran guru pendidikan Kristen disampaikan secara sederhana dan kontekstual dengan situasi dan kondisi budaya setempat.

Kedua, Yesus adalah sang guru yang Agung yang juga mengajar secara kontekstual. Yesus mengajar menggunakan kearifan lokal dan menggunakan perumpamaan yang ada di sekitar lingkungan tempat Dia mengajar, seperti: perumpamaan seorang penabur. Hal ini mengindikasikan bahwa setiap guru pendidikan Kristen yang mau menerapkan kontekstual dalam pengajarannya wajib mencontoh dan meneladani Yesus.

Ketiga, pendidikan kristen yang kontekstual dipahami dalam beberapa prinsip penting, yakni: (1) pendidikan Kristen harus diterapkan sesuai dengan gaya dan strategi mengajar mengajar Yesus, (2) pendidikan Kristen harus disesuaikan dengan situasi era industri 4.0, (3) pendidikan Kristen harus dapat diterima oleh setiap lapisan usia, (4) pendidikan Kristen tidak boleh kaku namun harus dinamis, implementatif, dan aplikatif, dan (5) pendidikan Kristen harus memberikan transformasi atau perubahan yang radikal.

\section{Referensi}

Agung, Imanuel, and Made Astika. "Penerapan Metode Mengajar Yesus Menurut Injil Sinoptik Dalam Pelaksanaan Pendidikan Agama Kristen Di SMA Gamaliel Makassar." Jurnal Jaffray 9, no. 2 (2011): 147-171.

Antone, Hope S. Pendidikan Kristiani Kontekstual: Mempertimbangkan Realitas Kemajemukan Dalam Pendidikan Agama. Jakarta: BPK Gunung Mulia, 2010.

Belo, Yosia. "PENDIDIKAN AGAMA KRISTEN DALAM MATIUS 28: 19-20." Jurnal LUXNOS 1, no. 2 (2020): 127-133.

D.A. Carson, R.T. France, J.A. Motyer, dan G.J. Wenham., ed. Tafsiran Alkitab Abad Ke-21 (Matius-Wahyu). Jakarta: YKBK/OMF, 2017.

David J. Hesselgrave; Edward Rommen. Contextualization: Meaning, Methods, and Models. Pasadena: William Carey Library, 1989.

Eliasaputra, Mark Phillips, Martina Novalina, and Ruth Judica Siahaan. "Tantangan Pendidikan Agama Kristen Di Era Revolusi Industri 4.0 Dan Pasca Kebenaran.” BONAFIDE: Jurnal Teologi Dan Pendidikan Kristen 1, no. 1 (2020): 1-22.

Fleming, Bruce C. Contextualization of Theology: An Evangelical Assessment. Pasadena: William Carey Library, 1980.

Heer, J.J. de. Tafsiran Alkitab Injil Matius. Jakarta: BPK Gunung Mulia, 2003.

Karnawati, K, H Hosana, and I Putu Ayub Darmawan. "Lingkungan Proses Pembelajaran Yesus." Veritas Lux Mea (Jurnal Teologi Dan Pendidikan Kristen) 1, no. 2 (2019): 7689. 
Keriapy, Frets. "Pendidikan Kristiani Transformatif Berbasis Multikultural Dalam Konteks Indonesia.” REGULA FIDEI: Jurnal Pendidikan Agama Kristen 5, no. 2 (2020): 82-93.

Kolibu, Dirk R, and Stenly R Paparang. "REVOLUSI PENDIDIKAN KRISTEN DI ERA INDUSTRI 4.0." Jurnal Dinamika Pendidikan 13, no. 2 (2020): 108-119.

Monding, Yushiko D. "Tinjauan Teologis Tentang Pendidikan Seks Dari Perspektif Pendidikan Kristiani Transformatif." Jurnal Teologi Pengarah 2, no. 2 (2020): 173182.

Moreau, A. Scott. Contextualizing the Faith:A Holistic Approach. Grand Rapids, MI: Baker Academic, 2018.

Morris, Leon. The Tyndale New Testament Commentaries: Luke. Surabaya: Momentum, 2007.

Nainggolan, John M. Guru Agama Kristen. Bandung: Jurnal Info Media, 2006.

Parhusip, Bongsu, Hasahatan Hutahaean, and Elda Theresia. "Penerapan Model ThinkPair and Share Dalam Meningkatkan Hasil Belajar PAK Pada Siswa SMP.” Didache: Journal of Christian Education 1, no. 2 (2020): 117-140.

Putra, Adi. "Kajian Biblika Terhadap Makna "Ta Stigmata Tou Iesou" Dalam Galatia 6:17.'” SUNDERMANN: Jurnal Ilmiah Teologi, Pendidikan, Sains, Humaniora dan Kebudayaan 13, no. 1, no. March, 2020 (2020).

Saenom. Pendidikan Agama Kristen Untuk Anak. Jakarta: Penerbit Vieka Wahana Semesta (Views), 2016.

Sihotang, Hermanto. "Penggunaan Media Teknologi Informasi Dalam Pembelajaran Pendidikan Agama Kristen Di Masa Pandemi Covid-19." IMMANUEL: Jurnal Teologi dan Pendidikan Kristen 1, no. 2 (2020): 63-75.

Sutoyo, Daniel. "Yesus Sebagai Guru Agung." Jurnal Antusias 3, no. 5 (2014): 64-85.

Tafonao, Talizaro. "Yesus Sebagai Guru Teladan Dalam Masyarakat Berdasarkan Perspektif Injil Matius." Khazanah Theologia 2, no. 1 (2020): 52-60.

Tamara, Yesi, Angel Christie Pakasi, Desserly Krismawaty Wesly, and Edi Sujoko. "Profesionalitas Yesus Sang Guru Agung Dalam Penggunaan Media Pembelajaran." Didache: Journal of Christian Education 1, no. 1 (2020): 65-76.

Telaumbanua, Arozatulo. "Peranan Guru Pendidikan Agama Kristen Dalam Membentuk Karakter Siswa." FIDEI: Jurnal Teologi Sistematika dan Praktika 1, no. 2 (2018): 219-231.

Til, Louis Berkhof; Cornelius van. Foundations of Christian Education. Surabaya: Momentum, 2012.

Tomatala, Yakob. Teologi Kontekstualisasi (Suatu Pengantar). Malang: Gandum Mas, 2018.

Yang, Ferry. Pendidikan Kristen. Surabaya: Momentum, 2018. 